\title{
Application of dry powders of six plant species, as soil amendments, for controlling Fusarium solani and Meloidogyne incognita on pea in pots
}

\author{
Hassan Abd-El-Khair and Wafaa M. A. El-Nagdi*
}

\begin{abstract}
Background: Application of organic amendments could improve soil properties as well as controlling of soil-borne pathogens. Soil amendments with dry powders of six plant species materials, i.e. caraway seeds, fennel seeds, garlic gloves, onion bulbs, pomegranate peel and spearmint leaves were separately applied for controlling Fusarium solani and Meloidogyne incognita on pea plants in pots. The control is untreated check pots for Fusarium solani and Meloidogyne incognita.
\end{abstract}

Results: The dry powder of pomegranate peel (as the rate of $10 \mathrm{~g} / 1 \mathrm{~kg}$ soil)highly reduced the Fusarium- disease assessments (pre-emergence and post-emergence damping-off and root-rot diseases incidence), followed by spearmint leaves, caraway seeds, fennel seeds, garlic gloves and onion bulbs, respectively. The tested dry powder of plant species showed the nematicidal activity on M. incognita criteria, i.e. second juvenile $\left(J_{2}\right)$ in soil and roots as well as galls and egg-masses in roots of pea. The spearmint leaves, onion bulbs and fennel seeds highly reduced the $J_{2}$ in soil and roots as well as galls and egg-masses. The pea plant growth parameters i.e. length of shoot, fresh \& dry weights of shoot and fresh weight of roots, yield parameters, i.e. fresh and dry weight of pea pod and pod parameters as well as Rhizobium nodules number were increased in pea plants with reducing infestation with F. solani and $M$. incognita.

Conclusions: Soil amendments with dry powders of six plant species materials were used in this study reduced $F$. solani and $M$. incognita and improved pea plants

Keywords: Dry powder, Fusarium solani, Organic amendments, Pisum sativum, Meloidogyne incognita

\section{Background}

Pea plants (Pisum sativum L.) are the most important vegetables crop grew in many countries of the world as well as in Egypt, where it is rich in starch, protein, Vitamins and high in fiber (Pownall et al. 2010). Fusarium solani (Fusarium root rot disease) and Meloidogyne incognita (nematode root-knot disease) are among various soilborne pathogens which attack pea root systems

\footnotetext{
*Correspondence: wafaaelnagdi@yahoo.com

Plant Pathology Department, National Research Centre, Dokki 12622 Cairo, Egypt
}

(Anwar and Mcknery 2010). Application of organic amendments could improve soil properties as well as controlling of soilborne pathogens, where the non-sterilized vegetables waste-compost completely inhibited the mycelium growth of Fusarium oxysporum f.sp radicislycopersici in tomatoes, at the highest rates only (Kouki et al. 2012). There were several medicinal plants as caraway seeds containing R-carvone and D-limonene, fennel seeds containing fenchone, camphene, garlic gloves powder containing allicin, onion bulbs powder containing flavonoids, phytosterols and saponins, pomegranate peel contain tannins, terpenoids, alkaloids, flavonoids and 
glycoside and spearmint leaves contain Mint L-carvone, limonene which have nematicidal effect (Middleton et al. 2000; Youssef and El-Nagdi 2016).

The un-autoclaved water extracts of commercial composts also had inhibitory effects against $F$. solani, isolated from cucumber plants, in vitro tests. The compost amended soil could reduce the percentages of disease incidence and improve the growth parameters of cucumber plants in pot experiments (Sabet et al. 2013).The pomegranate peel aqueous extract inhibited the linear growth of Fusarium oxysporum and F. solani in vitro tests as well as pomegranate peel powder, when tested as seed or soil treatments, could decrease the pre- emergence and post-emergence of Fusarium damping-off disease in greenhouse experiments (Mohamad and Khalil 2015). Application of pomegranate peel aqueous extract could reduce of wilting incidence and improve of growth variables of tomato plants in vivo tests (Rongai et al. 2016). The olive oil cakes or castor bean reduced Fusarium root rot disease incidence and increased the growth parameters of eggplants in pots experiment (Abd-El-Khair et al. 2018). The compost tea, when combined with pomegranate peel powder, highly inhibited the growth of $F$. oxysporum in vitro tests. The combination also significantly reduced the wilting disease severity and increased the survival of lupine plants in field applications (Abou ElNour Mona et al. 2020).

Application of aqueous or ethanol of stem extracts of Rhizophora mucronata showed more nematicidal effect against Meloidogyne javanica juveniles, than leaves extracts. Soil amended with dried powder of leaves or stem of R. mucronata controlled root-knot nematodes in plants of mash beans or okra, where the treatments also significantly increased the seeds germination and both length \& weights of shoot and root of tested plants (Tariq et al. 2007). The municipal green wastes, olive pomace, spent mushroom substrates and sewage sludge, when applied as soil amendments, could significantly reduce M. incognita parameters in tomato roots. Soil amended olive pomace-based composts or composted mushroom substrate resulted the highest nematode suppression and significantly increased the plant growth of tomato plants (D'addabbo et al. 2011). Dry leaves of both fleabane (F) and sugar beets (S), mud sugar beet (M) as well as organic compost, as sugar cane residues (OC), alone or in combination with Bionema (B) were significantly reduced the $M$. incognita parameters. The combination of Bionema + Nile fertile was reduced numbers of $\mathrm{J}_{2}$ nematode in soil as well as galls and egg-masses in roots, followed by $\mathrm{B}+\mathrm{M}, \mathrm{B}+\mathrm{OC}, \mathrm{B}+\mathrm{S}$ and $\mathrm{B}+\mathrm{F}$, respectively and significantly increased the growth parameters of sugar beet (El-Nagdi et al. 2011). Soil amended with chopped or ground dry leaves of neem and castor leaves had maximum suppression against gall and eggs numbers of $M$. javanica in greenhouse, respectively (Lopes et al. 2011). Soil amended with fresh chopped leaves or dry leaves powder of Datura stramonium, Peganum harmala or Tagetes minuta, poultry and sheep manure reduced the nematode population and improved plant growth parameters in garlic. $P$. harmala, as dry leaves powder, was the most effective (Saeed 2015).The olive oil cakes or castor bean reduced nematode parameters of $M$. incognita and increased the growth parameters of eggplants in pots experiment (Abd-El-Khair et al. 2018). The soil amended with ground seeds of fennel \& caraway or powdered leaves of basil significantly reduced the $M$. incognita parameters under greenhouse conditions. Basil waste was highly reduced numbers of $\mathrm{J}_{2}$ and egg-masses of nematode, than fennel and caraway, respectively. The treatments highly improved growth and yield parameters of M. incognita infected pea plants (El-Nagdi et al. 2019).

The present study aimed to evaluate the antifungal and nematicidal activity of powdered materials of six plant species, i.e. caraway seeds (Carum carvi)), fennel seeds (Foeniculum vierns), garlic gloves (Allium sativum), onion bulbs (Allium cepa), pomegranate peels (Punica granatum) and spearmint leaves (Mentha varidis) for controlling of Fusarium solani and Meloidogyne incognita on pea plants in pots.

\section{Methods}

\section{Dry plant materials}

Six dry materials of plant species i.e. caraway seeds (Carum carvi), fennel seeds (Foeniculum vierns), garlic gloves powder (Allium sativum), onion bulbs powder (Allium cepa), pomegranate peel (Punica granatum) and spearmint leaves (Mentha varidis) were obtained from Governorate of Fauyoum of Egypt during 2018 season. Then, the plant materials were dried at room temperature. Seeds of fennel, caraway, pomegranate peels and Spearmint leaves were ground in a blender. A commercial powdered of garlic gloves (Allium sativum) and onion bulbs (Allium cepa) were applied. All plant species were applied as powder materials, for testing their antifungal and nematicidal activity.

\section{Fusarium root-rot pathogen}

Fusarium solani was isolated from naturally infected pea plants and then the pathogenic fungus was identified in Plant Pathology Department (PPD), National Research Centre (NRC), according to pathological, morphological 
and cultural characters according to the key described by Ellis (1971) and Barnett and Hunter (1972).

\section{Meloidogyne incognita inoculum}

The root-knot nematode, $M$. incognita, was identified by using protocol described by Taylor and Sasser (1978) by using nematode adult female based on its perineal pattern morphological characteristics. The pure cultures of

\section{Effect on disease assessments of Fusarium solani}

Effect of dry powder of each caraway seeds, fennel seeds, garlic gloves, onion bulbs, pomegranate peels and spearmint leaves on disease assessments caused by $F$. solani was estimated. The pre-emergence and post- emergence of damping-off percentages were calculated after 15 and 45 days from sowing, respectively. The disease incidence (\%) of root- rots and survived of healthy pea plants were recorded after 60 days of sowing.

Pre - emergence $(\%)=$ Number of non - germinated seeds/Total number of sown seeds $\times 100$

Post - emergence $(\%)=$ Number of dead seedlings/Total number of sown seeds $\times 100$ Survived plant (\%) $=$ Number of survived plants/Total number of sown seeds $\times 100$

M. incognita were reared on eggplants by a single eggmass of this nematode inoculated to susceptible eggplant cv. Baladi in a screen house at $30 \pm 5{ }^{\circ} \mathrm{C}$. Newly hatched second juvenile of nematode as inocula were applied.

\section{Pot experiment}

Seventy of plastic pots (there were 35 pots for Fusarium experiment and 35 pots for nematode experiment), each of it contains about $2 \mathrm{~kg}$ of solarized sandy-loam soil (1:1), were applied. The treatments of dry powder materials were as follows; caraway seeds, fennel seeds, garlic gloves, onion bulbs, pomegranate peel, spearmint leaves and untreated (without pathogen). Each pot soil was mixed well with each tested dry powdered plant materials, separately, at rate $10 \mathrm{~g}$ per $1 \mathrm{~kg}$ soil. Then, the pots were watered and left for one week. The pots were divided into two groups; each one contains 35 pots, the first group for $F$. solani and the second for M. incognita. Five pots were used as replicated for each treatment. Seeds of pea (cv. Concessa) surface sterilized in solution of sodium hypochlorite (1\%) for $3 \mathrm{~min}$., followed by three successive rinses in sterilized-distilled water. The excess water was removed by air drying. In the group $\mathrm{A}$; the pots were inoculated with 7- days-old cultures $F$. solani adjusted to $10^{8}$ propagules/g at the rate of $3 \%$ soil weight (W: W) and then, the pots were watered and left for one week. Five seeds were sown in each pot. In the group (B); five pea seeds were sown per pot. After seeds germination, the two plants were selected in each pot. The pots were inoculated with 1000 newly hatched $\mathrm{J}_{2}$ of $M$. incognita in four holes made around the plant roots. The pots were arranged according to a complete randomized design on a bench of experimental greenhouse of PPD, NRC of Egypt.

\section{Effect on $M$. incognita parameters}

Three months after inoculation, the nematicidal effect of dry powder of each caraway seeds, fennel seeds, garlic gloves, onion bulbs, pomegranate peel and spearmint leaves against $M$. incognita criteria viz. $\mathrm{J}_{2}$ number in soil as well as numbers of $\mathrm{J}_{2}$, galls and egg-masses in pea roots (five roots /treatment) as well as the percentages of reduction were recorded.

\section{Effect on plant growth and pod parameters}

Effect of dry powder of each caraway seeds, fennel seeds, garlic gloves, onion bulbs, pomegranate peel and spearmint leaves on plant growth parameters of pea i.e., length of shoot $(\mathrm{cm})$, fresh \& root weights $(\mathrm{g})$ of shoot and fresh weight $(\mathrm{g})$ of roots as well as pod parameters, i.e. fresh and dry weights $(\mathrm{g})$ of pods were recorded with artificially infestation F. solani or M. incognita.

\section{Statistical analysis}

Results were analyzed by analysis of variance (ANOVA) using Computer Statistical Package Costat software (1990). User Manual Version 3.03, Barkley Co. The variation between treatments was detected using Duncan's multiple range test at $5 \%$ level of probability (Snedecor and Cochran 1999).

\section{Results}

Fusarium solani

\section{Effect on disease assessments}

The antifungal activity of dry powders of six plant species, i.e. caraway seeds, fennel seeds, garlic gloves, onion bulbs, pomegranate peel and spearmint leaves on Fusarium -disease assessments, in pots experiment, are listed in Table 1. The pomegranate peel highly increased the survival pea plants being $86.1 \%$, followed by spearmint leaves $(83.0 \%)$, caraway seeds $(79.0 \%)$, fennel seeds 
Table 1 Effect of dry powder plant materials on disease assessments of Fusarium solani as well as number of Rhizobium nodules in pea roots system in pots, under greenhouse conditions

\begin{tabular}{|c|c|c|c|c|c|c|}
\hline \multirow[t]{4}{*}{ Treatments $^{1}$ (dry powder) } & \multicolumn{4}{|c|}{ Disease assessments (\%) } & \multicolumn{2}{|c|}{ Nodules no } \\
\hline & \multicolumn{2}{|l|}{ Damping-off } & \multirow[t]{3}{*}{ Root rot incidence } & \multirow[t]{3}{*}{ Survival plants } & \multirow[b]{3}{*}{$\log _{10}$} & \multirow[b]{3}{*}{ Incr.\% } \\
\hline & Pre-emergence & Post-emergence & & & & \\
\hline & & & & & & \\
\hline Caraway seeds & $9.4 b^{2}$ & $10.7 b$ & $10.3 b c$ & 79.0ab & 14 & 17 \\
\hline Fennel seeds & $9.4 b$ & $13.9 b$ & $13.9 \mathrm{bc}$ & $72.2 b c$ & 13 & 8 \\
\hline Garlic gloves & $12.5 b$ & $14.3 b$ & $14.3 b c$ & $71.4 \mathrm{bc}$ & 14 & 17 \\
\hline Onion bulb & $12.5 b$ & 17.9ab & $17.9 \mathrm{~b}$ & $64.2 \mathrm{C}$ & 14 & 17 \\
\hline Pomegranate peel & $6.3 b$ & $6.7 \mathrm{~b}$ & $7.2 \mathrm{c}$ & $86.1 \mathrm{a}$ & 13 & 8 \\
\hline Spearmint leaves & $6.3 b$ & $7.2 \mathrm{~b}$ & $9.8 b c$ & 83.0ab & 16 & 33 \\
\hline F. solani alone & $31.3 a$ & $27.5 a$ & $31.7 a$ & $40.8 d$ & 12 & - \\
\hline
\end{tabular}

${ }^{1}$ All treatments were done with artificial infection by $F$. solani alone

${ }^{2}$ Means followed by small letter are not significant according to Duncan's Multiple Range Test at $p \leq 0.05$

(72.2\%), garlic gloves (71.4\%) and onion bulbs (64.2\%), respectively (Table 1).

Results revealed that the incidence of pre-emergence of damping-off disease was in the ranges of 6.3 to $12.5 \%$, in treated pea plants, compared to $31.3 \%$ in pea plants treated with $F$. solani only. The dry powders of each pomegranate peel and spearmint leaves highly reduced the disease incidence to $6.3 \%$, followed by each of caraway seeds \& fennel seeds (9.4\%) and each of garlic gloves \& onion bulbs (12.5\%), respectively. Results revealed that the post-emergence of damping-off disease incidence was in the ranges of 6.7 to $17.9 \%$, than $27.5 \%$ in pea plants treated with $F$. solani only. The dry powder of pomegranate peel highly reduced the disease incidence to $6.7 \%$, followed by spearmint leaves (7.2\%), caraway seeds (10.7\%), fennel seeds (13.9\%), garlic gloves (14.3\%) and onion bulbs (17.9\%), respectively (Table 1 ).

The incidence of root rot disease in treated plants with dry powder of plant species was ranged from 7.2 to $17.9 \%$ in treated plants, compared to $31.7 \%$ in pea plants treated with $F$. solani only. The antifungal activity of tested dry powders were same trend as mentioned before, where the pomegranate peel highly reduced the root-rot incidence to $7.2 \%$, followed by spearmint leaves $(9.8 \%)$, caraway seeds $(10.3 \%)$, fennel seeds (13.9\%), garlic gloves (14.3\%) and onion bulbs (17.9\%), respectively. Results revealed that plant dry powders were increased the survival pea plants in the range of 71.4 to $86.1 \%$, compared to survival plants being $40.8 \%$ with $F$. solani only.

\section{Effect on plant growth and pod parameters}

Effects of plant dry powders on growth parameters of pea plants i.e. length of shoot, fresh \& dry weights of shoot and fresh weight of roots as well as yield parameters, i.e. fresh and dry weights of pea pods, with artificially infestation with $F$. solani in pot experiment, is shown in Table 2. The pomegranate peel highly increased being $58 \%$, followed by onion bulbs (46\%), garlic gloves (42\%), fennel seeds (39\%), caraway seeds (31\%) and spearmint leaves (31\%), respectively.

The plant dry powders increased the shoot length of treated plants in the ranges of 11 to $25 \%$ comparing $F$. solani treatment only. The pomegranate peel resulted the highest increases being $25 \%$, followed by garlic gloves (21\%), onion bulbs (19\%), spearmint leaves $(16 \%)$, fennel seeds (15\%) and caraway seeds (11\%), respectively. The fresh and dry weights of shoot of treated pea plants were in the ranges of 4 to $34 \%$ and 46 to $133 \%$ comparing with pathogen only. The pomegranate peel highly increased of each fresh and dry weights being 34 and 133\%, followed by onion bulbs ( $24 \& 127 \%$ ), garlic gloves ( 15 \& 106\%), spearmint leaves ( $11 \& 100 \%)$, fennel seeds ( $4 \& 46 \%)$ and caraway seeds ( $9 \& 73 \%$ ). Results revealed that the fresh weight in treated pea roots ranged 31 to $58 \%$ comparing with pathogen only.

The plant dry powders increased the fresh pod of treated pea in the range of 60 to $110 \%$ comparing with pathogen only. The pomegranate peel has the highest increased being $110 \%$, followed by onion bulbs (89\%), garlic gloves $(70 \%)$, caraway seeds $(60 \%)$, fennel seeds $(60 \%)$ and spearmint leaves (60\%), respectively. The treatments also increased the dry weight of pea pod in the ranges of 35 to $91 \%$ comparing with pathogen only. The pomegranate peel also highly increased being $91 \%$, followed by onion bulbs $(87 \%)$, garlic gloves $(61 \%)$, spearmint leaves (52\%), fennel seeds (39\%) and caraway seeds (35\%), respectively (Table 2 ). 


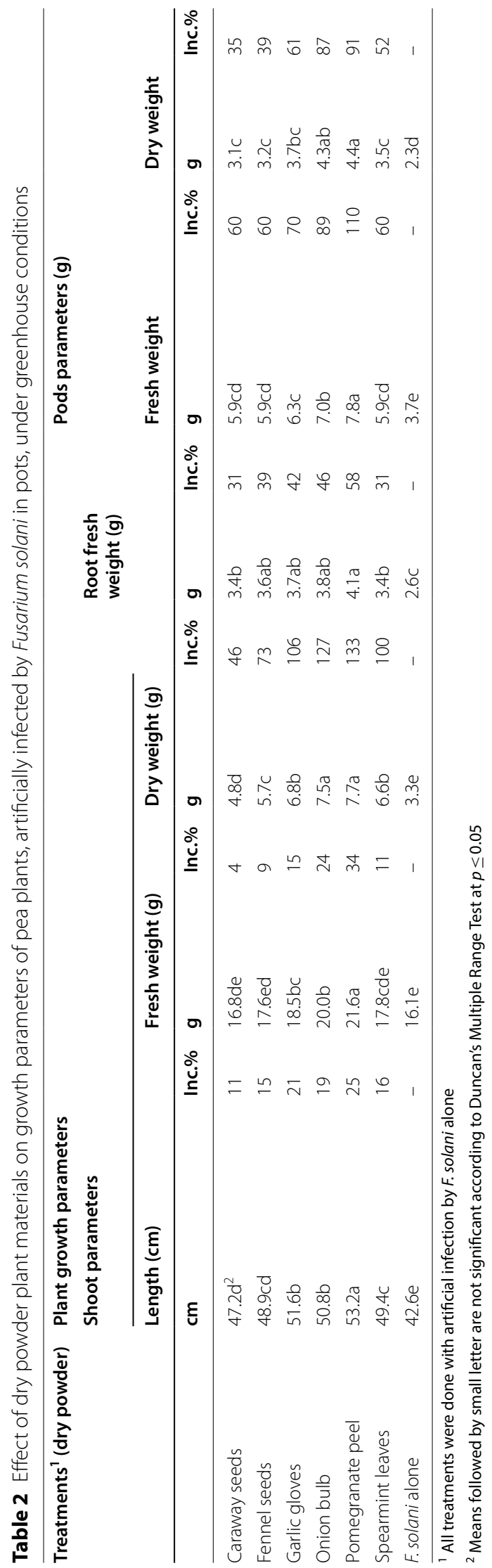




\section{Meloidogyne incognita Effect on nematode parameters}

The nematicidal activity of plant dry powder, i.e. caraway seeds, fennel seeds, garlic gloves, onion bulbs, pomegranate peel and spearmint leaves against $M$. incognita parameters, i.e. $\mathrm{J}_{2}$ in soil and $\mathrm{J}_{2}$, galls and egg-masses in roots in pots are shown in Table 3 . The dry powders reduced the $\mathrm{J}_{2}$ numbers in soil in the ranges of 63 to $89 \%$ comparing with the untreated control $(M$. incognita alone). The spearmint highly increased the $\mathrm{J}_{2}$ reduction in soil being $89 \%$, followed by fennel seeds $(88 \%)$, caraway seeds $(86 \%)$, pomegranate peel $(80 \%)$, onion bulbs $(79 \%)$ and garlic gloves (63\%), respectively. The treatments also reduced the $\mathrm{J}_{2}$ number in roots in the ranges of 61 to $75 \%$ comparing with untreated control. The onion bulbs highly increased the percentages of root- $\mathrm{J}_{2}$ reduction being $75 \%$, followed by garlic gloves (72\%), fennel seeds (69\%), pomegranate peel (67\%), caraway seeds (64\%) and spearmint leaves (61\%), respectively (Table 3$)$.

The plant dry powders could reduce the galls number in roots in the ranges of 63 to $79 \%$ comparing with untreated control. The fennel seeds highly increased the percentages of galls reduction in pea roots being $79 \%$, followed by garlic gloves (74\%), pomegranate peel (74\%), caraway seeds $(68 \%)$, onion bulbs $(63 \%)$ and spearmint leaves (63\%), respectively. The treatments also reduced the egg-masses number in pea roots in the ranges of 67 to $83 \%$, comparing with untreated control. The fennel seeds highly increased the percentages of egg-masses reduction in pea roots being $83 \%$, followed by garlic gloves (75\%), onion bulbs (75\%), pomegranate peel $(75 \%)$, caraway seeds (67\%) and spearmint leaves $(67 \%)$, respectively (Table 3).

\section{Effect on plant growth and pod parameters}

Effects of plant dry powders on tested pea plant growth parameters as well as pod parameters with artificially infestation with $M$. incognita, in pot experiment are shown in Table 4. The shoot length of treated pea plants was in the ranges of 10 to $26 \%$ comparing with nematode alone. The pomegranate peel highly increased the shoot length being $26 \%$, followed by onion bulbs (20\%), garlic gloves $(18 \%)$, fennel seeds (14\%), spearmint leaves (14\%) and caraway seeds (10\%), respectively. The shoot fresh and dry weights of treated pea plants were in the ranges of 9 to $36 \%$ and 17 to $59 \%$, respectively. The pomegranate peel highly increased the shoot fresh and dry weights being 36 and 59\%), followed by onion bulbs (24 \& 55\%), garlic gloves (17 \& 35\%), spearmint leaves (15 \& 28\%), fennel seeds (11 \& 24\%) and caraway seeds (9 \& 17\%), respectively. The fresh weight of pea roots was in the ranges of 14 to $46 \%$ comparing with pathogen only. The fennel seeds highly increased the root weight being $46 \%$, followed by garlic gloves (43\%), pomegranate peel (39\%), onion bulbs (26\%), garlic gloves (42\%), spearmint leaves (29\%) and caraway seeds (14\%), respectively. The plant dry powders also increased the fresh pod in treated pea plants ranged from 71 to $141 \%$ comparing with untreated control. The pomegranate peel highly increased the fresh pod weight being $141 \%$, followed by onion bulbs (129\%), garlic gloves (109\%), spearmint leaves (97\%) fennel seeds (85\%) and caraway seeds $(71 \%)$, respectively. The dry weight of pea pod improved in the ranges of 23 to $104 \%$. The pomegranate peel has highest increase of dry weight of pod being $104 \%$, followed by onion bulbs (92\%), garlic gloves (81\%), fennel seeds (58\%), spearmint leaves (50\%) and caraway seeds (23\%), respectively (Table 4 ).

Table 3 Effect of dry powder plant materials on M. incognita parameters and Rhizobium bacterial nodules number in pea roots system in pots, under greenhouse conditions

\begin{tabular}{|c|c|c|c|c|c|c|c|c|c|c|}
\hline \multirow[t]{3}{*}{ Treatments $^{1}$ (dry powder) } & \multicolumn{7}{|c|}{$\begin{array}{l}\text { Nematodes } \\
\text { parameters }\end{array}$} & \multirow{2}{*}{\multicolumn{3}{|c|}{ Nodules no }} \\
\hline & \multicolumn{2}{|l|}{$\mathrm{J}_{2}$ in soil } & \multicolumn{2}{|c|}{$\mathrm{J}_{2}$ in roots } & \multicolumn{2}{|c|}{ Galls No } & Egg-masses No & & & \\
\hline & $\log _{10}$ & Red. \% & $\log _{10}$ & Red. \% & $\log _{10}$ & Red. \% & $\log _{10}$ & Red. \% & $\log _{10}$ & Red. \% \\
\hline Caraway seeds & $3.00 c^{2}$ & 86 & $2.11 b$ & 64 & $0.78 b$ & 68 & $0.59 b$ & 67 & $15 b$ & 50 \\
\hline Fennel seeds & $3.43 b$ & 88 & $2.04 b$ & 69 & $0.59 d$ & 79 & $0.26 c$ & 83 & $15 b$ & 50 \\
\hline Garlic gloves & $3.43 b$ & 63 & $2.00 \mathrm{~b}$ & 72 & $0.69 c$ & 74 & $0.46 b$ & 75 & $15 b$ & 50 \\
\hline Onion bulb & $3.19 c$ & 79 & $1.95 c$ & 75 & $0.84 b$ & 63 & $0.46 b$ & 75 & $12 \mathrm{~cd}$ & 20 \\
\hline Pomegranate peel & $3.16 c$ & 80 & $2.00 c$ & 67 & $0.69 c$ & 74 & $0.46 b$ & 75 & $13 c$ & 30 \\
\hline Spearmint leaves & $2.91 \mathrm{C}$ & 89 & $2.15 b$ & 61 & $0.84 b$ & 63 & $0.59 b$ & 67 & $18 a$ & 80 \\
\hline M. incognita alone & $3.86 a$ & - & $2.55 a$ & - & $1.28 \mathrm{a}$ & - & $1.07 a$ & - & $10 d$ & - \\
\hline
\end{tabular}

${ }^{1}$ All treatments were done with artificial infection by M. incognita alone

${ }^{2}$ Means followed by small letter are not significant according to Duncan's Multiple Range Test at $\mathrm{p} \leq 0.05$ 


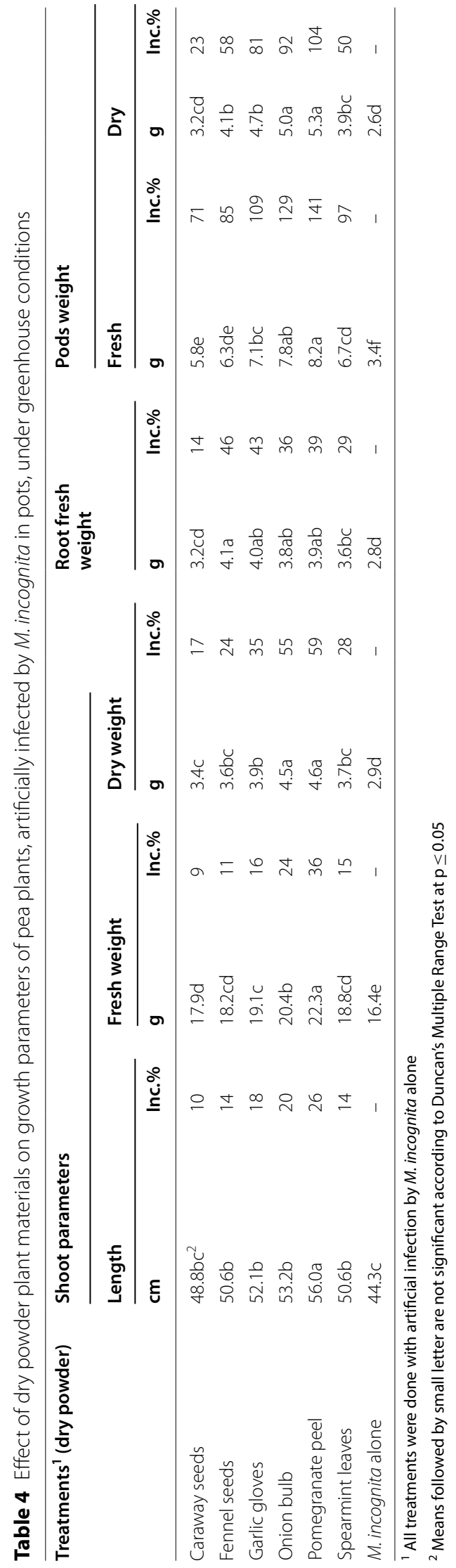




\section{Effect on Rhizobium nodules}

The pots experiment revealed that the increase of Rhizobium nodules number was in the ranges of $8-33 \%$ in treated pea roots comparing with $F$. solani only. The spearmint leaves highly increased the Rhizobium nodules being $33 \%$, followed by caraway seeds (17\%), garlic gloves (17\%), onion bulbs $(17 \%)$, fennel seeds $(8 \%)$ and pomegranate peel (8\%), respectively (Table 1$)$. Under artificially infestation with $M$. incognita, the number of Rhizobium nodules on pea roots was in the ranges of $20-80 \%$ comparing with untreated control. The spearmint leaves also highly increased the Rhizobium nodules being $80 \%$, followed by caraway seeds (50\%), fennel seeds, $(50 \%)$, garlic gloves $(50 \%)$, onion bulbs $(20 \%)$ and pomegranate peel (30\%), respectively (Table 2 ).

\section{Discussion}

Application of organic soil amendments could improve the physical \& chemical properties, structure, temperature and humidity conditions of soil as well as nutrient contents for plants growth. The beneficial bacteria or fungi play an important role in suppressing the economically important soil borne disease (plant parasitic nematodes or pathogenic fungi).Organic amendments can provide an environmentally friendly alternative to chemical pesticide uses which are often expensive, limited available or environmentally hazardous (Renčo 2013). The use of organic amendments, a narrow $\mathrm{C}: \mathrm{N}$ ratio, can improve soil fertility, whereas more efficiently can reduce the levels of nematode and could minimize the risks of increase levels of others soil-borne pathogens, where neem seeds powder has nematicidal activity in field or greenhouse (Agbenin 2004). Application of the leaves and stem of Avicennia marina or Rhizophora mucronata, as organic amendments, significantly controlled root rot fungi (Fusarium spp.) and root-knot nematode (Meloidogyne javanica) in potato in pots (Tariq et al. 2008). The olive pomace composts significantly increased soil chemical parameters as organic matter, where the nitrogen contents were at the highest rates (D'addabbo et al. 2011).

Our results revealed that the dry powders of tested plant species were differed in their antifungal or nematicdal activity against Fusarium-disease assessments or $M$. incognita-nematode parameters of $M$. incognita in potted pea plants, where the reduction differed according to treatment. The dry powders of pomegranate peel or spearmint leaves, resulted the highest reduction against incidence of pre- and post-emergence dapping-off as well as root rot diseases, than other plant dry powders when pea plants were artificially infested with $F$. solani. The obtained results are in agreement with those recorded by Borrego-Benjumea Ana et al. (2015), where soil amended with poultry manure or olive residue compost significantly reduced inoculum viability of Fusarium oxysporum, $F$. proliferatum and $F$. solani associated with asparagus roots when affected with crown and root rot diseases. The root severity disease symptoms significantly decreased, where $F$. proliferatum was lower severity, than $F$. oxysporum or F. solani. Soil amended with olive residue compost showed significantly asparagus plants fresh weight with Fusarium infection. Javaid and Rauf (2015) showed that the dry leaves of Chenopodium album significantly reduced disease incidence of basal rot in onion caused by $F$. oxysporum when incorporation at $3 \%(\mathrm{w} / \mathrm{w})$. The chloroform, resulted from methanolic leaf extract, exhibited the best antifungal activity against fungal biomass. Therefore, the chloroform fraction or soil amendment with biomass of $C$. album dry leaves can apply as alternative of chemical fungicides for controlling basal rot disease in onions. Rongai et al. (2016) mentioned reduced the Fusarium population in soil as well as the compost tea in combination with pomegranate peel powder because of it has an important source of bioactive compounds which managed Fusarium wilt and increase in number of healthy tomato plants. It is cleared that pomegranate peel may be a promising as an environmentally safe alternative to fungicides by suppressing the most dangerous damping-off and wilt diseases (Abou ElNour et al. 2020).

Under artificially infestation with $M$. incognita, the applied plant dry powders could reduce the nematode parameters, but no significant differences were recorded with most treatments. The dry powders of spearmint leaves, onion bulbs and fennel seeds had the highest nematicidal activity against of $\mathrm{J}_{2}$ in soil \& roots as well as galls \& egg-masses. These results are in agreement with those recorded by Stirling and Eden (2008) and Youssef and El-Nagdi (2016-2017) on spearmint. They reported that soil amended with sugarcane residue, plus ammonium nitrate, enhanced microbial activity and decreased M. incognita populations when incorporated at 4 months before planting of capsicum. Soil amendments of olive pomace or composted mushroom substrate significantly reduced gall formation of $M$. incognita in tomato roots, whereas the composted municipal green wastes were more suppressive when combined with sewage sludge (D'addabbo et al. 2011). The bio-fumigation by mechanically incorporation of chopped brassicaceous plants into soil controlled soil-borne nematode. Bio-fumigant effect may due to the volatile or toxic of thiocyanates originated from the of secondary metabolites hydrolysis of glucoseinolate present in the Brassica tissues. The graminaceous plants such as sorghum and Sudan grass produce nematicidal cyanides via enzymatic hydrolysis of precursor cyanogenic glycoside/dhurrin. The allelopathic plant marigold produces $\alpha$-terthienyl, which has shown 
potential bio-fumigation effect against PPNs (Dutta et al. 2019).

Our results revealed that the dry powders of six plants species were increased the tested plant growth and pods parameters of pea plants in comparing pathogen alone, where the increase differed according to treatment. The leaves and stem of Avicennia marina or Rhizophora mucronata, as organic amendments, significantly increased the plant growth (length of shoot, weight of shoot, length of roots and weight of roots) of potato (Tariq et al. 2008). The compost of olive-waste was positively affected tomato growth, when combined with wastes of sheep wool. Soil amendments with composted mushroom substrate significantly increased the growth of plants, whereas composted municipal green waste was positively affected tomato growth in combination with sewage sludge (D'addabbo et al. 2011). The certain medicinal chopped plant green or dry leaves and their aqueous extracts of neem, Datura, camphor and oleander managed root knot nematode $M$. incognita criteria as well as plant growth parameters in eggplant and reduction differed according to treatment. The most plant growth parameters were increased by some treatments (Youssef and Lashein 2013).The powdered dry leaves of spearmint and sage alone or in combination were reduced M. incognita on cowpea and improving plant growth and yield criteria (El-Nagdi Wafaa et al. 2017).

\section{Conclusions}

Soil amendments with dry powders of six plant species, i.e. caraway seeds, fennel seeds, garlic gloves, onion bulbs, pomegranate peel and spearmint leaves were used in this study reduced $F$. solani and $M$. incognita criteria which subsequently improved plant growth and yield of pea plants. The pomegranate peel highly increased the survival pea plants infected by $F$. solani followed by spearmint leaves, caraway seeds, fennel seeds, garlic gloves and onion bulbs. The onion bulbs highly increased the percentages of nematode $\mathrm{J}_{2}$ reduction, followed by garlic gloves, fennel seeds, pomegranate peel, caraway seeds and spearmint leaves. It is clear that the leaves and seeds of Egyptian plant species may have best control against Fusraium pathogen or rootknot nematode as well as improved plant growth and yield when applied in the field.

\footnotetext{
Abbreviations

M. incognita: Meloidogyne incognita; $J_{2}$. Second stage juveniles; F. solani: Fusarium solani; F. oxysporum: Fusarium oxysporum; R. mucronata: Rhizophora mucronata; F: Dry leaves of fleabane; M: Mud sugar beet; OC: Organic compost as sugar cane residues; B: Incombination with bionema; PPD: Plant Pathology Department; NRC: National Research Centre; ANOVA: Analysis of variance; COSTAT: Computer statistical package.
}

Acknowledgements Not applicable.

\section{Authors' contributions}

H A E (The first author) suggested the idea of the research and design the experiment in green house, shared in writing the manuscript. W M AE (second author) carried out the manuscript in the green house, statistical analysis in data, shared in writing the manuscript. The two authors read and approved the final manuscript.

\section{Funding}

There is no funding.

\section{Availability of data and materials}

Soil amendments with dry powders of some plant species materials, are available for controlling Fusarium solani and Meloidogyne incognita.

\section{Declarations}

Ethics approval and consent to participate Not applicable.

\section{Consent for publication}

Not applicable.

\section{Competing interests}

The authors declare that they have no competing interests.

Received: 11 November 2020 Accepted: 6 June 2021

Published online: 22 June 2021

\section{References}

Abd-El-Khair H, El-Nagdi WMA, Hammam MMA (2018) Effect of olive and castor bean oil cakes singly or combined with Trichoderma spp on Fusarium solani and Meloidogyne incognita infecting Eggplant. Middle East J Appl Sci 8:465-473

Abou El-Nour Mona M, Sarhan EAD, Wadi Mona JM (2020) Suppressive effect of compost/pomegranate peel tea combination against Fusarium oxysporum f. sp. Iupini and Rhizoctonia solani as an alternative synthetic fungicide. Egypt J Exp Biol (bot) 16:13-25

Agbenin ON (2004) Potentials of organic amendments in the control of plant parasitic nematodes. Plant Prot Sci 40:21-25

Anwar SA, Mcknery MV (2010) Incidence and reproduction of Meloidogyne incognita on vegetable crop genotypes. Pak J Zool 42:135-141

Barnett HL, Hunter BB (1972) Illustrated genera of imperfect fungi. Burgess Publ. Co., Minnesota, p 241

Borrego-Benjumea Ana I, Melero-Vara JM, Basallote-Ureba María J (2015) Organic amendments conditions on the control of Fusarium crown and root rot of asparagus caused by three Fusarium spp. Spanish. J Agric Res 13:e1009

Costat software (1990) Microcomputer program analysis, version 4. 20, CoHort Software, Berkely, CA, USA

D’addabbo T, Papajová I, Sasanelli N, Radicci V, Renčo M (2011) Suppression of root-knot nematodes in potting mixes amended with different composted biowastes. Helminthologia 48:278-287

Dutta TK, Khan MR, Phani V (2019) Plant-parasitic nematode management via biofumigation using brassica and non-brassica plants: current status and future prospects. Curr Plant Biol 17:17-32

Ellis MB (1971) Dematiaceous hyphomycetes. Commw. Mycol. Inst. Kew. Surrey, England

El-Nagdi Wafaa MA, Abd El Fatta Al (2011) Controlling root-knot nematode, Meloidogyne incognita infecting sugar beet using some plant residues, a biofertilizer, compost and biocides. J Plant Prot Res 51:107-113

El-Nagdi Wafaa MA, Youssef MMA, Dawood Mona G (2017) Nematicidal activity of certain medicinal plant residues in relation to controlling root knot nematode, Meloidogyne incognita on cowpea. Appl Sci Rept 20:35-38

El-Nagdi Wafaa MA, Youssef MMA, Abd El-Khair H, Abd-Elgawad MMM (2019) Effect of certain organic amendments and Trichoderma species on the 
root-knot nematode, Meloidogyne incognita, infecting pea (Pisum sativum L) plants. Egypt J Biol Pest Control 29:75

Javaid A, Rauf S (2015) Management of basal rot disease of onion with dry leaf biomass of Chenopodium album as soil amendment. Int J Agric Biol 17:142-148

Kouki S, Saidi N, BenRajeb A, Brahmi M, Bellila A, Fumio M, Hefiene M, Jedidi N, Downer J, Ouzari H (2012) Control of Fusarium wilt of tomato caused by Fusarium oxysporum f.sp. radicis-lycopersici using mixture of vegetable and Posidonia oceanica compost. Appl Environ Soil Sci. https://doi.org/10. 1155/2012/2396

Lopes EA, Ferraz S, Ferreira PA, de Freitas LG, Dallemole-Giaretta R (2011) Soil amendment with chopped or ground dry leaves of six species of plants for the control of Meloidogyne javanica in tomato under greenhouse conditions. Ciência Rural 41:935-938

Middleton E Jr, Kandaswami C, Theoharides TC (2000) The effects of plant flavonoids on mammalian cells: implications for inflammation, heart disease and cancer. Pharmacol Rev 52:673-751

Mohamad Tahany GM, Khalil Amal A (2015) Effect of agriculture waste: pomegranate (Punica granatum L.) fruits peel on some important phytopathogenic fungi and control of tomato damping-off. J Appl Life Sci Int 3:103-113

Pownall TL, Udenigwe CC, Aluko RE (2010) Amino acids composition and antioxidant properties of pea seed (Pisum sativum) enzymatic protein hydrolysate fractions. J Agric Food Chem 58:4712-4718

Renčo M (2013) Organic amendments of soil as useful tools of plant parasitic nematodes control. Helminthologia 50:3-14

Rongai D, Pulcini P, Pesce B, Milano E (2016) Antifungal activity of pomegranate peel extract against Fusarium wilt of tomato. Eur J Plant Pathol $146: 229-238$

Sabet KK, Saber MM, El-Naggar MA, El-Mougy Nehal S, El-Deeb HM, El-Shahawy IE (2013) Using commercial compost as control measures against cucumber root-rot disease. J Mycol 6:1-13
Saeed MRM (2015) Efficacy of some organic amendments for the control of stem and bulb nematode, Ditylenchus dipsaci (Kühn) Filipjev on garlic (Allium sativum). Egypt J Agronematol 14:22-36

Snedecor GW, Cochran WG (1999) Statistical methods, 5th edn. lowa State University Press, Ames, p 593

Stirling GR, Eden LM (2008) The impact of organic amendments, mulching and tillage on plant nutrition, Pythium root rot, root-knot nematode and other pests and diseases of Capsicum in a subtropical environment, and implications for the development of more sustainable vegetable farming systems. Australas Plant Pathol 37:123-131

Taylor AL, Sasser JN (1978) Biology, identification and control of root-knot nematodes (Meloidogyne species). IMP, North Carolina State University Graphics, Raleigh

Tariq M, Dawar S, Mehdi FS, Zaki MJ (2007) Use of Rhizophora mucronata in the control of Meloidogyne javanica root knot nematode on okra and mash bean. Pak J Bot 39:265-270

Tariq M, Dawar S, Mehdi FS, Zaki MJ (2008) The effect of mangroves amendments to soil on root rot and root knot of potato (Solanum tuberosum L.). Acta Agrobot 61:115-121

Youssef MMA, El-Nagdi Wafaa MA (2016-2017) Population density of root knot nematode, Meloidogyne incognita infecting eggplant influenced by intercropping with spear mint plants; a pilot study. Bull NRC 41(1):264-270

Youssef MMA, Lashein Asmahan MS (2013) Efficacy of different medicinal plants as green and dry leaves and extracts of leaves on root knot nematode, Meloidogyne incognita infecting eggplant. Eur J Agric Environ Med 2:10-14

\section{Publisher's Note}

Springer Nature remains neutral with regard to jurisdictional claims in published maps and institutional affiliations.

\section{Submit your manuscript to a SpringerOpen ${ }^{\circ}$ journal and benefit from:}

- Convenient online submission

- Rigorous peer review

- Open access: articles freely available online

- High visibility within the field

- Retaining the copyright to your article

Submit your next manuscript at $\boldsymbol{\nabla}$ springeropen.com 